\title{
Journals Read by ACRL Academic Librarians, 1973 and 1978
}

\begin{abstract}
A study was undertaken to identify the amount and kinds of professional journal reading being done by ACRL academic librarians, with data drawn from two separate surveys made over a five-year period of time. Questionnaires were sent to a sample of ACRL members in 1973 and again in 1978, which ascertained how many journals they were reading regularly and what the titles of those journals were. Illustrations provide a comparison of most frequently read titles for 1973 to 1978, with the percentage of reader response for each title. For both years surveyed, ACRL academic librarians averaged approximately seven journals read on a regular basis. A separate analysis of the 1978 data indicated that 7 percent of the titles cited as being read accounted for 80 percent of the journal reading. As had been the case in 1973, more than nine in ten of these academic librarians were regular readers of College \& Research Libraries (C\&RL). However, several other titles heavily cited in 1973 lost readership among ACRL members due to the dramatic appearance of the Journal of Academic Librarianship.
\end{abstract}

$\mathrm{T}$ HE SOLIDIFIED INTEREST in the use of information and in the audiences of information systems, is a fundamental development of the last two decades. With a combination of eclectic techniques and methods ranging from citation analysis and other bibliometric techniques, to the investigation of the actual information-seeking behavior of users, we have begun the arduous yet important task of describing and generalizing the informationseeking behavior of our audiences.

Curiously, there remains at least one audience that lags far behind as a focus of such attention and subsequent analysis. While our research has something to say about the scientist and the engineer, the student and the researcher, the physician, the disciplinarian, it has very little to say about the informationseeking behavior of a profession whose very reason for existence is facilitating the flow of information: academic librarians.

Robert Swisher is associate professor and Peggy C. Smith is assistant professor, School of Library Science, University of Oklahoma at Norman.
As academic librarians, we make decisions daily about whether or not to seek out information, and where and how to acquire it. To aid in the articulation of academic librarians' information needs, it is important to identify the journals ACRL academic librarians tend to read regularly. Do academic librarians read journals that are more closely associated with traditional definitions of their collective purview (administration, technical services, reference, the publishing industry, etc.), or do the titles that they read allow us to redefine the scope of their collective professional concern? What are the other journals that academic and research librarians read regularly? Have these patterns of readership changed over time?

\section{Related Research}

Several studies have included the number of professional journals read by librarians and have used this information-seeking behavior as an indicator of professionalism (Stone, Nash, Plate, McClure). ${ }^{1-4}$ Stone created an index to measure professionalism 
that included familiarity with professional literature. ${ }^{5}$ Her sample was not limited to academic librarians, however, which was also the case with Nash's survey, in which he measured communication characteristics of public library administrators. ${ }^{6}$

There have been studies devoted to the examination of professional characteristics and behavior of academic librarians, ${ }^{7,8}$ but ACRL membership has not been surveyed as a target population. In addition, the comparability of the results of such studies suffers in that "reading" is defined operationally in various ways: scanning a journal issue, subscribing to journal titles, reading for certain purposes only, etc. However, these studies do offer benchmarks concerning typical behavior and are therefore useful.

There are also limited data available concerning the specific titles read by librarians. Target populations for these studies vary considerably, of course, and reflect the specific interests of these groups. ${ }^{9}$

An indication of the potential diversity of professional reading for academic librarians is pointed out in articles whose authors champion reading journals related to information science, nonlibrary specializations, ${ }^{10}$ administration, and higher education. ${ }^{11}$

\section{INSTRUMENT DEVELOPMENT and SuRvey Design}

In the spring of 1973 data were collected by questionnaire on the communication behavior, job/situational, and education characteristics of academic librarians holding membership in the Association of College and Research Libraries (ACRL). Of the instrument's twenty-two questions, two dealt specifically with the reading behavior of ACRL academic librarians. In November 1978 , five and a half years later, the same questionnaire was sent to a second sample of ACRL academic librarians.

The research instrument, developed in 1973, and used for both the 1973 and 1978 data collection, was a synthesis of new items and items adopted from two existing instruments, one developed by Stone, ${ }^{12}$ the other by A. Schiller. ${ }^{13}$ Stone's work had identified several dimensions of professional communication, while Schiller's study offered baseline data on the characteristics of a large sample of academic librarians. Instrument develop- ment included modifications suggested by a panel of content experts and a pretest on a sample of thirty members of the population. Using both a postcard technique ${ }^{14}$ to ensure anonymity, and a second wave for nonrespondents, the following results were obtained: Of the three hundred ACRL members sampled in 1973, 259 (or 86.3 percent) returned usable questionnaires within fortyfive days. The response rate for the $1978 \mathrm{sam}$ ple was 83.2 percent, with 357 usable questionnaires returned from 429 ACRL members. One question dealt with the library-related titles they read regularly for purposes other than materials selection; another question asked about other (nonlibrary) professional titles they read regularly.

\section{SAMPLING}

The sampling frame for the 1973 data was taken from the 1972 American Library Association Membership Directory, a directory that included more than 31,000 entries. From the directory, a list was drawn of 4,100 individuals, including all personal, nonstudent, and noninstitutional members of the Association of College and Research Libraries who could be identified as having an affiliation with an academic or research library in the United States.

In the absence of other current supplementary evidence of population variability, the pretest statistics concerning the total number of memberships held in professional, scholarly, and honorary organizations were used in determining minimum sample size needed. The formula used to estimate the minimum sample size needed for this 1973 survey was that given by Cochran for continuous data in the presence of a finite population. ${ }^{15}$

Selecting a confidence interval of 95 percent, and a half-width of 5 percent of the value of the mean, a minimum sample size of 240 was determined. Considering the age of the directory information from which this sample was drawn, as well as the typical amount of nonresponse and unusable returns to be encountered in questionnaire mailings, the computed minimum sample size was increased by 25 percent, or sixty names, and the final sample size drawn randomly from the sampling frame was 300 names.

Although the percentage of usable re- 
sponses received from the 1973 sample was quite high (86.3 percent), a simple check was made during data analysis to assess nonresponse bías.

The results of these analyses indicated that there was no evidence to suggest that the responses of early respondents systematically differed from the latest respondents. As had been expected in light of the high response rate, there was no evidence of nonresponse bias.

The procedures and instrument used for the 1978 survey of college and research librarians holding membership in ACRL were comparable to those used in gathering the 1973 data.

The directory used to obtain the 1978 sample was a current printout of 7,110 individuals holding personal membership in ACRL. Instead of actually determining that exact subset of the 7,100 who fit the criteria for inclusion in the sampling frame, the investigators choose rather to (1) take a larger systematic random sample than was estimated to be necessary, (2) analyze this much shorter list against the inclusion criteria, (3) discard names of individuals who could be definitely verified as not currently employed in college or research libraries, and (4) send questionnaires to those who still could not be definitely verified as appropriate. A note requesting that they disregard the questionnaire if they were not a member of the target population was included with a request to return the enclosed postcard with an indication of their current job status.

Questionnaires were sent to 503 persons, including a questionable group of 158 who could not be verified as appropriate.
Including two waves of mailings with questionnaires returned over a period of forty-eight days, 373 questionnaires and 71 postcards indicating inappropriateness to respond were received. Of the 373 questionnaires returned, 357 were complete and usable for data analysis.

In light of data gathered through the special note applied to those questionnaire recipients who the investigators could not determine to be members of the target population, at most 429 members of the sample of 503 were actively employed in academic and research libraries. The response rate to the 1978 survey was therefore at least 83.2 percent and probably higher since an unknown portion of the nonrespondents were not members of the target population, but didn't return their postcards indicating that fact. As was the case with the 1973 survey data, checks were made to determine any differences between early and later responses. Again, no systematic differences were detected, and considering the high response rate it was concluded that serious nonresponse bias did not exist.

\section{Data Description}

As can be seen from table 1, two of the three measures of central tendency were quite similar for both the total number of journals read among the 1973 respondents and the 1978 respondents. In general, both groups were regularly reading close to seven journals on the average. However, it was the case that the 1978 distribution exhibited more positive skew than the 1973 distribution. In terms of variability, the 1978 sample yielded a slightly larger standard deviation

TABLE 1

Descruptive Statistics and Confidence Intervals FOR NUMBER OF LIBRARY, NONLIBRARY, aNd TOTAL JOURNALS READ BY 1973 and 1978 SAMples of ACRL ACAdEMiC Librarians

\begin{tabular}{lcccccr}
\hline \hline & Library & $\begin{array}{c}1973 \\
\text { Nonlibrary }\end{array}$ & Total & Library & $\begin{array}{c}1978 \\
\text { Nonlibrary }\end{array}$ & Total \\
\hline Central Tendency & 5.8 & 1.0 & 6.8 & 5.9 & 1.3 & 7.2 \\
Mean & 5.1 & 0.4 & 6.1 & 5.4 & 0.6 & 6.4 \\
Mode & 3.0 & 0.0 & 3.0 & 5.0 & 0.0 & 5.0 \\
Dispersion & & & & & & \\
S.D. & 3.4 & 1.5 & 4.1 & 3.3 & 1.9 & 4.4 \\
Range & 20. & 7. & 25 & 28 & 18 & 46 \\
95\% C.I. & 5.4 & 0.8 & 6.3 & 5.6 & 1.1 & 6.7 \\
Low & 6.2 & 1.2 & 7.3 & 6.2 & 1.5 & 7.7 \\
High & 0.9 & 1.6 & 1.1 & 1.7 & 2.9 & 2.5 \\
Skew & & & & & & \\
\hline
\end{tabular}


and a much higher absolute range. While the 1973 sample ranged from no journals read to twenty-five journals read regularly, the 1978 sample ranged from zero to forty-six. Still, there was no significant difference between the mean number of journals read between the two samples: the 95 percent confidence interval ranged from 6.27 to 7.34 for the 1973 data, and overlapped with the confidence interval of 6.73 to 7.65 for the 1978 data.

The total number of journals read was actually a computed variable composed of two separate components; library-related journals read and nonlibrary professional journals read. Again, comparing 1973 data with 1978 data, there was no significant difference according to the average number of library journals read by these academic librarians. In 1973, an average of 5.78 library journals were read regularly. In 1978, the mean number of library journals read was 5.9. It can be seen from the comparison of the confidence intervals that no significant differences existed. Again, the range for the 1978 data was larger; however, there was less variability in terms of the standard deviation. Also, the amount of positive skew again increased from 1973 to 1978.

It is interesting to note that similar studies support the wide range of number of journals read by librarians. For example, Plate's study indicates that 48 percent of the respondents read between five and nine journals. ${ }^{16}$ Although Stone's study yields a slightly lower average number of journals read, Stone's population of library school graduates read an average of 3.6 library journals regularly. ${ }^{17}$ Another investigation including public library administrators provided an average of 2.37 library periodicals read on a regular basis. ${ }^{18}$

The nonlibrary journals read, both in 1973 and 1978, was low. In 1973 the librarians read on the average one nonlibrary professional journal regularly during the previous twelve months. In 1978, that mean figure increased to 1.3. In both cases the modal value was zero: most academic librarians were not reading any nonlibrary journals regularly. Quite consistently the 1978 distribution exhibited more skew than 1973 distribution. Also, the range of nonlibrary journals read was considerably higher in 1978 . As was the case with the comparison of total journals read and library journals read from 1973 to 1978 , there was no practical difference between the 95 percent confidence intervals.

Again, the average number of nonlibrary journals read by library school graduates in Stone's survey was less than the average number read by academic librarians in this survey. Stone's survey results in 1971 revealed that 58.8 percent of the academic librarians were not reading regularly any other professional journals. ${ }^{19}$

Eighty-five percent of the 1973 journals read were library titles. Eighty-two percent of the 1978 journal reading was from libraryrelated journals. The striking features of the comparison across five years were the similarities. Measures of central tendency were essentially the same. The only differences worthy of mention concern dispersion and skew. For both range and skew the 1978 data were higher than the 1973 data. While the averages were the same, the 1978 sample showed greater variability. Of the three distributions (nonlibrary, library, and total journals read), nonlibrary journals read appears to fit most closely the characteristics of a Poisson distribution, a distribution that applies to infrequently occurring events. ${ }^{20}$

\section{Results}

The left side of table 2 shows, in decreasing rank order, the seventeen most frequently cited journal titles for the 1973 baseline sample. The frequency of the first two titles, American Libraries and College \& Research Libraries, was anticipated since membership in the ACRL means the reception of both titles automatically. Indeed, it could be posited that the frequency with which they were cited was actually low; after all, 10 percent of these ALA academic librarians were not reading the official publication of the professional association in which they held membership. Fourteen percent of the respondents were not reading the official journal of the specific division within ALA to which they belonged. Yet, the purposely restrictive definition of reading could have accounted for this discrepancy; "regular reading" was defined on the questionnaire as almost never missing an issue, and it was further stipulated that titles only glanced through quickly were 
TABLE 2

Rank Order of the Seventeen Most Frequently Read Journals in 1973 and 1978, with PERCENt ReAding

\begin{tabular}{|c|c|c|c|c|}
\hline \multirow[b]{2}{*}{ Rank } & \multicolumn{2}{|c|}{1973} & \multicolumn{2}{|c|}{1978} \\
\hline & Title & $\begin{array}{l}\text { Percent } \\
\text { Reading }\end{array}$ & Title & $\begin{array}{l}\text { Percent } \\
\text { Reading }\end{array}$ \\
\hline 1 & American Libraries & 90.0 & American Libraries & 92.2 \\
\hline 2 & $C \triangleleft R L$ & 86.1 & $C \triangleleft R L$ & 88.6 \\
\hline 3 & $L J$ & 69.9 & $L J$ & 69.3 \\
\hline 4 & LRTS & 57.9 & $J A L$ & 44.0 \\
\hline 5 & $R Q$ & 38.2 & LRTS & 36.3 \\
\hline 6 & WLB & 37.4 & $R Q$ & 33.3 \\
\hline 7 & $P W$ & 30.9 & WLB & 27.4 \\
\hline 8 & Lib Trends & 23.6 & $P W$ & 26.0 \\
\hline 9 & Lib Quarterly & 22.8 & Lib Trends & 20.0 \\
\hline 10 & $J O L A$ & 20.9 & Chronicle Higher Ed & 19.7 \\
\hline 11 & Special Libraries & 17.4 & Lib Quarterly & 18.0 \\
\hline 12 & JASIS & 12.4 & Special Libraries & 17.5 \\
\hline 13 & AAUP Bulletin & 8.9 & JOLA & 16.1 \\
\hline 14 & JEL & 6.6 & JASIS & 10.0 \\
\hline 15 & LC Information Bul & 4.6 & Change & 5.8 \\
\hline 16 & Chronicle Higher Ed & 4.6 & AAUP Bulletin & 5.0 \\
\hline 17 & Today's Education & 4.6 & Today's Education & 4.7 \\
\hline
\end{tabular}

not to be counted. In any event, it was still the fact that these two titles alone accounted for fully one-fourth of the regular reading done by the 1973 group.

The third title, Library Journal $(L J)$ was the only title in the first five not published by the association, and seven in ten members of the 1973 sample read it regularly. The high rankings of the next two titles, Library Resources of Technical Services (LRTS) and $R Q$, as well as their rank relative to one another, almost surely reflected a degree of overlap with the other ALA divisions they represent. A related fact was that a higher percentage of the 1973 respondents viewed their job activity as involving technical services ( 48.2 percent) than those who indicated that their professional activity was related to public services (43.6 percent). ${ }^{21}$ (The first five titles, four of which were published by the association, accounted for one-half of the reading of the 1973 sample.)

The final ALA publication ranked in the top seventeen titles was the Journal of $\mathrm{Li}$ brary Automation (JOLA). JOLA, which ranked tenth, was read regularly by 21 percent of the first sample. Heading the list of titles ranked fifth through tenth, however, were Wilson Library Bulletin (WLB), and Publishers Weekly (PW)-two titles published by commerical publishers closely associated with libraries and librarianship. $\mathrm{Li}$ brary Trends and Library Quarterly, the eighth and ninth titles, were unique among the top ten in that they were university press publications editorially associated with professional library education. Of the first ten titles (which cumulatively accounted for, now, 70 percent of the reading done by the first sample), three were commercial products, two were products of academe, and five were the products of the association.

The remaining titles on the list of seventeen most frequently cited were very different from the first ten in terms of sponsorship. Five of these titles indicated at least shared interests in, if not actual membership in, other organizations: Special Libraries Association, the American Society for Information Science, the American Association of University Professors, the American Association of Education for Librarianship, and the National Education Association. The two other titles, Library of Congress' Information Bulletin and the Chronicle of Higher Education, were tied at rank sixteen with the NEA Journal, and all seventeen titles together accounted for slightly less than 80 percent of the first sample's journal reading.

Results - Titles-1978

A comparison of the seventeen most frequently mentioned titles between the baseline sample of 1973 and the sample five years later reveals instances of both great stability and dramatic change (see table 3 ). As indi- 
TABLE 3

Rank Order of the Twenty-Six Most Frequently Read Journals in 1978, with Percent Reading, Percent of All Titles Cited

\begin{tabular}{|c|c|c|c|c|}
\hline Rank & Titles & $\begin{array}{l}\text { Percent of } \\
\text { Respondents } \\
\text { Reading }\end{array}$ & $\begin{array}{c}\text { Cum } \\
\text { Percent } \\
\text { of All } \\
\text { Titles } \\
\text { Cited }\end{array}$ & $\begin{array}{l}\text { Cum Percent } \\
\text { of All } \\
\text { Reading } \\
\text { Done }\end{array}$ \\
\hline 1 & American Libraries & 92.2 & 0.25 & 13.0 \\
\hline 2 & College \& Research Libraries & 88.6 & 0.50 & 25.4 \\
\hline 3 & Library Journal & 69.3 & 0.75 & 35.2 \\
\hline 4 & Journal of Academic Librarianship & 44.0 & 1.00 & 41.4 \\
\hline 5 & LRTS & 36.3 & 1.25 & 36.5 \\
\hline 6 & $R Q$ & 33.3 & 1.50 & 51.2 \\
\hline 7 & Wilson Library Bulletin & 27.4 & 1.75 & 55.0 \\
\hline 8 & Publishers Weekly & 26.0 & 2.00 & 58.7 \\
\hline 9 & Library Trends & 20.0 & 2.25 & 61.5 \\
\hline $10^{*}$ & Chronical of Higher Education & 19.7 & 2.50 & 64.3 \\
\hline 11 & Library Quarterly & 18.0 & 2.75 & 66.8 \\
\hline 12 & Special Libraries & 17.5 & 2.98 & 69.3 \\
\hline $13^{*}$ & JOLA & 16.1 & 3.23 & 71.5 \\
\hline 14 & JASIS & 10.0 & 3.48 & 72.9 \\
\hline $15^{*}$ & Change & 5.8 & 3.73 & 73.8 \\
\hline $16^{*}$ & AAUP Bulletin & 5.0 & 3.98 & 74.5 \\
\hline $17^{*}$ & Today's Education & 4.7 & 4.23 & 75.1 \\
\hline 18 & Journal of Education for Librarianship & 4.2 & 4.48 & 75.2 \\
\hline $19^{*}$ & Serials Librarian & 3.6 & 4.73 & 76.2 \\
\hline $20.5^{*}$ & LC Information Bulletin & 3.3 & 5.22 & $\overline{-1}$ \\
\hline $20.5^{*}$ & Doc. to the People & 3.3 & 5.22 & 77.1 \\
\hline $22.5^{*}$ & AVI Audiovisual Instruction & 3.1 & 5.97 & - \\
\hline $22.5^{*}$ & Science & 3.1 & 5.97 & 78.4 \\
\hline 24.5 & Government Pub. Review & 1.9 & 6.96 & $-\overline{0}$ \\
\hline $24.5^{*}$ & Illinois Libraries & 1.9 & 6.96 & 79.6 \\
\hline 26 & American Archivist & 1.7 & 7.21 & 79.8 \\
\hline
\end{tabular}

-Journal was not listed on the questionnaire, but respondents listed in addition to titles provided.

cated in the right side of table 2 , the first three titles-American Libraries, C\&RL, and Library Journal retained their previous order of frequency, and showed no significant gain or loss in percentage of respondents reading them: it was still the case in 1978 that nine in ten were reading American Libraries, followed closely by College \& Research $\mathrm{Li}$ braries. Also, seven in ten still read Library Journal regularly. A dramatic change, though, was the high percentage of readership captured by a title introduced into the market after the 1973 survey: the Journal of Academic Librarianship (JAL). Fourth on the 1978 frequency ranking and read by 44 percent of the sample, JAL was preceded by only Library Journal as a non-ALA publication read by academic librarians holding membership in ACRL.

At this point in the analysis of the 1978 list it is important to note that only three of the journal titles on the earlier list of the top seventeen titles had actual gains or losses exceeding 5 percent. LRTS dropped from 57.9 per- cent of readership to 36.3 percent readership, Wilson Library Bulletin dropped form 37.4 percent to 27.4 , and the Chronicle of Higher Education increased from 4.6 percent in 1973 to 19.7 percent in 1978 . The greatest absolute change, a loss of 21.6 percent, was suffered by LRTS, and is most probably accounted for by two factors: (1) it was partially displaced by the appearance of $J A L$; and (2) the percentage of respondents who claimed that their major library activity was solely in a technical service area or in the administration of a technical service area, dropped from 32.8 percent of the 1973 sample to 17.0 percent of the 1978 sample - the composition of the ACRL membership had also changed in the interim.

$R Q$, ranked sixth in reading frequency in 1978, lost 4.9 percent from its baseline percentage - again probably due to the appearance of $J A L$. Indeed, it fared better than it might have, considering the losses of the titles just above and below it on the 1978 list. However, with the loss of librarians involved 
in technical services as a percentage of the composition of the 1978 sample, came a comparable rise in the percentage of public service librarians, which increased from 28.2 percent of the 1973 sample to 38.1 percent of the later sample. The percentage loss of Wilson Library Bulletin, however, could not be explained by some degree of give and take among divisions within ALA, as could that of LRTS and RQ.

Comparatively insignificant losses were associated with the eighth and ninth titles on the 1978 list, Publishers Weekly and Library Trends. The Chronicle of Higher Education, ranked tenth in 1978, made a dramatic gain over the 1973 baseline data. While only 4.6 percent of the earlier sample of ACRL members read it regularly, 19.2 percent attended to it in 1978.

Again, insignificant changes occurred for the next four journals on the 1978 listLibrary Quarterly, Special Libraries, JOLA, and JASIS. Special Libraries, in fact, held the same percentage of the ACRL audience in spite of the appearance of two new titles ranked above it in 1978, JAL and the Chronicle. Change magazine, ranked above it in 1978 , increased in audience percentage from 1.5 percent to 5.8 percent. AAUP Bulletin, which ranked thirteenth and was read by 8.9 percent of the earlier sample, dropped to a rank of sixteen in 1978 and lost more than one-half of its share of the reading audience. The Journal of Education for Librarianship (JEL) and the LC Information Bulletin were missing from the 1978 list of top seventeen titles; however, JEL only dropped from 6.6 percent in 1973 to 4.2 percent in 1978 . Similarly, LC's Information Bulletin dropped from 4.6 to 3.3 percent.

Of the twenty-five journals listed, it is interesting that two of the top fifteen most frequently mentioned are nonlibrary-related journals, the Chronicle of Higher Education and Change magazine.

The Chronicle of Higher Education was regularly read by 20 percent of the respondents, although approximately half of the publication is job announcements, a fact that might help explain why the Chronicle is ranked higher than Library Quarterly or Special Libraries. However, the Chronicle does cover library-related news, the rising cost of library acquisitions, research efforts of the Library of Congress, and the status of the National Periodicals Center. ${ }^{22}$

Two other predominantly higher education publications were listed, with approximately 5 percent of the respondents reading Change, and 5 percent reading AAUP Bulletin regularly. The omission of the leading research journal for higher education, the Journal of Higher Education, should be noted. ${ }^{23}$ Where the leading research journals for academic librarianship are read frequently, the leading research journal for higher education was replaced by newsoriented publications for its field.

It is evident that journal reading as a professional activity of ACRL academic librarians has remained constant. The average number of journals regularly read remained the same from 1973 to 1978 . Further, a comparison of the seventeen most frequently read titles showed great similarity as well: not only were they reading the same number on the average, but also the titles read and the percentages in which they were reading them were very similar. The three most frequently cited titles, American Libraries, College \& Research Libraries and Library Journal accounted for more than one-third of all the journal reading activity.

There were differences, however, almost all of which can be attributed to two titles, Journal of Academic Librarianship and the Chronicle of Higher Education. A new title, $J A L$, was read by four in ten of the librarians in 1978. Also, the Chronicle, which was read by less than 5 percent of the respondents in the 1973 sample, increased its readership fourfold and was read by almost 20 percent of the respondents in 1978.

The displacement due to JAL is not difficult to explain. It is, after $C \triangleleft R L$, the only other title specifically devoted to the broad field of academic librarianship. The increase exhibited by the Chronicle is not as straightforward. While other titles dealing with education did not show increase in readership from 1973 to 1978 (Change, Today's Education, AAUP Bulletin), the Chronicle increased by 15 percent.

It seems reasonable to assume that the Chronicle's increased readership was partially due to increased attention to the professional positions that it listed and its focus on the problems and prospects of higher education during a period of small growth and even real decline. 


\section{REFERENCES}

1. Elizabeth W. Stone, "A Study of Some Factors Related to the Professional Development of Librarians" (Ph.D. dissertation, American Univ., 1968), p.81.

2. William V. Nash, "Characteristics of Administrative Head of Public Libraries in Various Communication Categories" (Ph.D. dissertation, Univ. of Illinois, 1964), p.114.

3. Kenneth H. Plate, Management Personnel in Libraries: A Theoretical Model for Analysis (Rockaway, N.J.: American Faculty Press, 1970), p.90.

4. Charles R. McClure, Information for Academic Library Decision Making: The Case for Organizational Information Management (Westport, Conn.: Greenwood, 1980), p.75.

5. Stone, “A Study of Some Factors," p.81.

6. Nash, "Characteristics of Administrative Head,"p.4.

7. Elizabeth W. Stone, "Quest for Expertise: A Librarian's Responsibility," College \& Research Libraries 32:432-41 (Nov. 1971).

8. "Top Brass Librarians Read Most Literature," Library Journal 94:4330 (Dec. 1, 1969).

9. P. Dansey, "Do Information Scientists Read About Information Science?" The Information Scientist 6, no.3:109 (Sept. 1972).

10. Stone, "Quest for Expertise," p.432.

11. Norman D. Stevens, "Current Periodicals in
Higher Education: A Review Article," Journal of Academic Librarianship 5:338 (Jan. 1980).

12. Stone, "A Study of Some Factors," p.433-45.

13. Anita R. Schiller, Characteristics of Professional Personnel in College and University Libraries (Springfield, Ill.: Illinois State Library, 1969), p.115-18.

14. Robert D. Swisher "Professional Communication Behavior of Academic Librarians Holding Membership in the American Library Association" (Ph.D. dissertation, Indiana Univ., 1975), p.70.

15. William G. Cochran, Sampling Techniques (2d ed.; New York: John Wiley, 1963), p.76.

16. Kenneth Plate, Management Personnel in Libraries: A Theoretical Model for Analysis N.J.: American Faculty Press, 1970), p.90.

17. Stone, "A Study of Some Factors," p.81.

18. Nash, "Characteristics of Administrative Head," p.114.

19. Stone, “Quest for Expertise,"p.432.

20. Swisher, "Professional Communication Behavior," p.91.

21. Stevens, "Current Periodicals in Higher Education," p.338.

22. Peggy C. Smith, "Books Published in Higher Education: A Study of the Most Cited and Significant" (Ph.D. dissertation, Univ. of Oklahoma, 1979), p.55. 